\title{
Management of Technological Development of the Region: Ecosystem Approach
}

\begin{abstract}
Marina Evseeva*
Ural State University of Economic, 620144 Yekaterinburg, Russia

*Corresponding author.Email: m.evseeva@inbox.ru

ABSTRACT

The current stage of technological development is characterized by several important trends. First, the current level of technology limits the ability of companies to develop and apply them independently. Companies unite in business networks, forming stable dynamic network structures, where the emergence and diffusion of technologies occurs in the inter-company space. Secondly, the network nature of company interactions is deepening due to the large-scale development of digital technologies. This entails not only the emergence of distributed industries and centers of innovation, but also the blurring of the boundaries of traditional markets and industries. Third, in the context of globalization, the process of creating a final product can be distributed among companies located in different countries. In this case, the issue of manufacturability of national economies is actualized, and not of local types of economic activity. Thus, the main drivers of technological growth are not individual companies and industries, but inter-firm and intersectoral cooperation, which makes the issue of the development of ideas about regional technology ecosystems actual.
\end{abstract}

Keywords: technology, ecosystem, industry, technological development.

\section{INTRODUCTION}

Technological development is a key driver of economic growth. This was noted by Karl Marx in the theory of value. The influence of the level of technologies used on economic growth has been studied for a long time and has been proven both theoretically and empirically. Technological development occurs through the continuous renewal of traditional and the emergence of fundamentally different technologies. New technologies can completely replace old ones, or they can change and expand their traditional configuration and structure [1].

From the point of view of N. Kondratyev's theories of long cycles and J. Schumpeter's innovation cycles, technological development is based on abrupt structural and technological shifts initiated by the emergence of new basic technologies. Later, G. Mensch discovered that pauses in economic dynamics are associated with the exhaustion of the development potential of the basic technology, when the marginal utility of improving technologies begins to tend to zero. He called this phenomenon "technological stalemate" and suggested that the pattern of its occurrence is associated with the imposition of trajectories of cyclical development of basic technologies. As a result, a structural crisis develops, the economy is characterized by instability and turbulence. However, it is the "technological stalemates" that stimulate the emergence of new basic technologies and, as a result, accelerate technological development. The Mensch model formed the basis of the concept of the techno-economic paradigm of C. Freeman and C.Perez. The techno-economic paradigm is a set of clusters understood as large-scale basic technologies. Freeman and Perez believed that basic technologies appear discretely, while improving ones go on continuously, so technological development is the evolution of technoeconomic paradigms, and their change determines large cycles. What is important in this concept is that each subsequent paradigm originates in the growth phase of the previous one and its further development and dominance depends on the relevant transformation of the institutional structure.

The key process of technological development is not only the emergence and change of new technologies, but also their dissemination, which occurs through training (E. Rogers' model of diffusion of innovations), making decisions about the feasibility of using technology in response to changes in the external environment, making decisions based on expected efficiency. 
The emergence of a new basic technology to some extent forms the trajectory of further technological development in the form of waves of improving technologies. G. Dosi was the first to draw attention to this, introducing the concept of a technological paradigm as a socially accepted model for solving technological problems. Later, A. Payne clarified the interpretation of the technological paradigm as the result of the interaction of the material and cognitive components of technology, which is essentially a "stream of behavioral practices" that largely depend on the emerging institutional conditions [2]. The downside of the programmability of the trajectory of technological development and its inertia is the so-called "technological trap" effect, first described by P. David in posing the question of the effectiveness of the selection of technological standards [3].

The current stage of technological development is distinguished by a pronounced nonlinear nature and a complex convergent technological structure. For example, digital technology is not just a fast-growing industry of a new technological order. Penetrating into all spheres of social production, they serve as the basis for the operational transformation of all traditional and new industries. Massive online communications, reducing the distance and time for making decisions, led to a sharp increase in the dynamism of the environment and increased uncertainty. Direct connections between market exchange participants eliminate price mechanisms for balancing supply and demand, and competition in local markets for output volumes is replaced by global competition for technological leadership [4].

However, despite the rapid development of digital technologies, humanity cannot fully move into virtual space. Material objects produced by traditional industries will always be the basis of human life. In addition, despite globalization and the constant modification of technological chains and networks, enhanced by the possibilities of digitalization (the developers of one technology may be on opposite ends of the globe), the territorial aspect is still extremely important for the materialization of production technologies [5].

\section{METHODS - ECOSYSTEM APPROACH}

We have chosen the ecosystem approach as a basic one. The ecosystem approach methodology is based on the idea that no economic agent, institution or structure develops in isolation from the environment formed by them and other participants. The concept of ecosystems arose as a result of the synthesis of network and evolutionary theory as a development of the theory of organizational populations by $\mathrm{M}$. Hannan and J. Freeman, which is based on the postulate of the domination of "collective rationality over individual". This means that the optimality of the action can be interpreted differently for an individual company and for the industry (or a certain set of firms) as a whole.

Along with the processes of adaptation of ecosystem participants to each other and to changes in the external environment, the development of business ecosystems is associated with the accumulation of technological knowledge. Ecosystems operate on the principles of collaboration, understood as "a process of continuous formal and informal agreements between autonomous agents, as a result of which rules are created. These rules are shared by all participants and bring them mutual benefits "[6]. In further studies of ecosystems, the main focus has shifted from its participants to the nature and dynamics of internal interactions. And the ecosystems themselves were considered as a dynamic set of multidimensional internal connections, which include, in addition to economic agents, an ecosystem environment consisting of technologies, rules of the game, and culture. J. Jacobidis distinguishes three groups of ecosystem studies depending on the point of reference of the ecosystem environment - a firm, an innovation, or a platform [7]. The studies of the first group are focused, in fact, on the study of the ecosystem as a community of interacting agents and the ways of the firm's formation of sustainable competitive advantages, taking into account the dynamics of the ecosystem. The second group of studies is focused on examining how the integration of economic agents takes place in the mainstream of a single innovation for its development and commercialization. The key issue is the coordination mechanisms between the owner of the main innovation and the owners of complementary innovations [8]. In a number of studies, a geographically localized innovation ecosystem associated with industrial organizations is associated with a cluster in its modern sense. The third group of research focuses on platform ecosystems. We are talking specifically about technological and digital platforms formed by the core and the network of peripheral firms. The platform is based on technology formalized in the form of technological standards. The technology owner firm acts as the platform coordinator, and the peripheral firms are the suppliers of add-ons (complementors) that make the platform product more valuable.

Thus, in terms of the problems of managing the technological development of the region, the ecosystem approach allows us to represent the technological structure of the territory in the form of an ecosystem of technologies.

\section{FORMATION OF A REGIONAL TECHNOLOGY ECOSYSTEM}

We used the technology hierarchy representation widely used in foreign literature. According to this approach, all technologies are classified into basic, component and system technologies. 


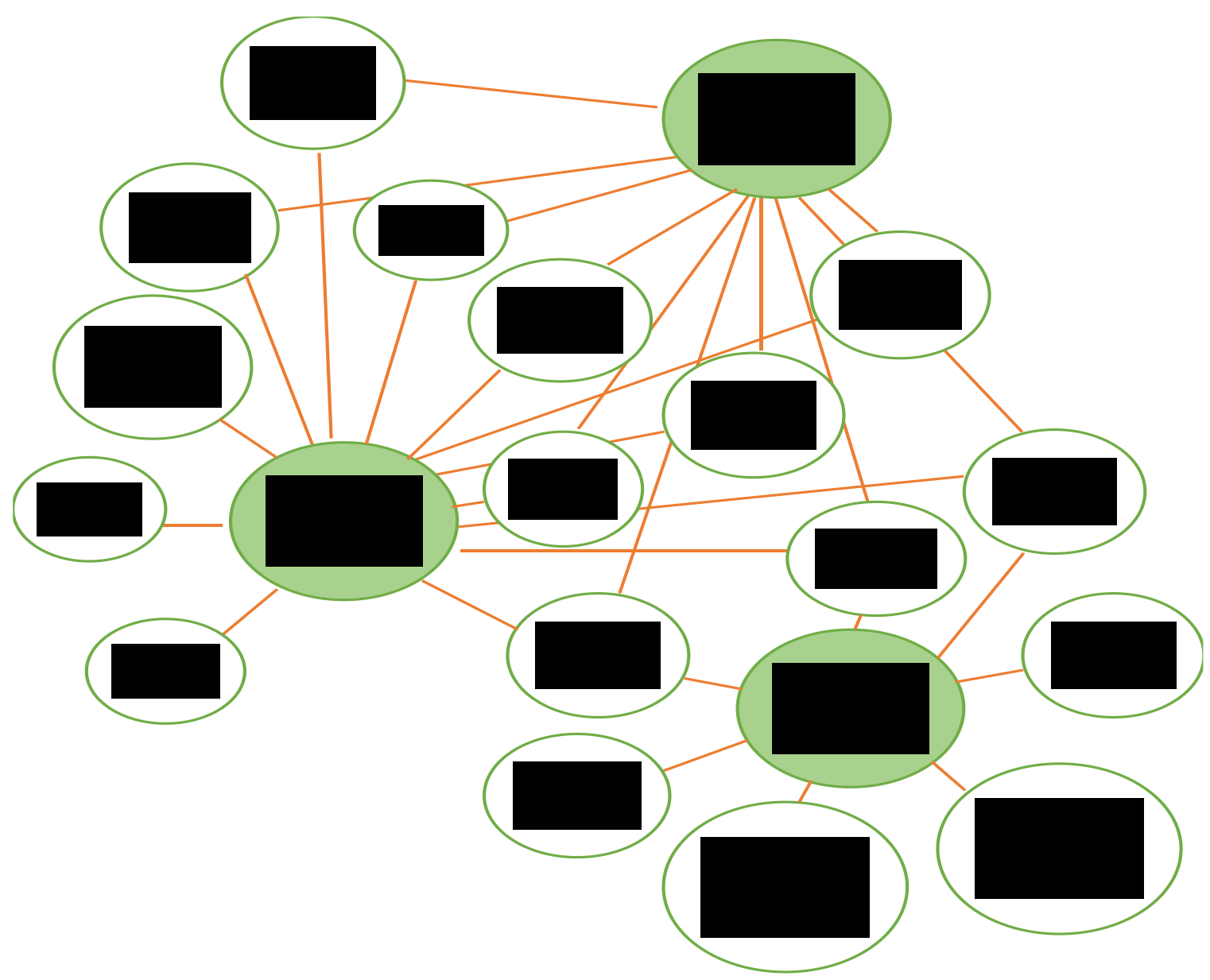

Figure 1 Fragment of the regional technology ecosystem.

System technology meets one or more functional requirements of end users and is implemented through the integration of several hardware and software products called component technologies. Component technologies support system technology, but generally cannot fulfill the functional requirements of users separately. Basic technologies are the primary technologies that enable component-level technologies to be implemented. An example of the implementation of a system technology is a passenger aircraft, a component technology - an aircraft turbine engine, a basic technology - an alloy for the manufacture of a turbine blade for an aircraft engine [9].

We believe that enterprises - carriers of system technologies stimulate the development of component technologies in the region, thereby forming industrial ecosystems and being their explicit or implicit mediators. Over time, the established structure of component technologies begins to determine the development of certain system technologies on the territory of the region. Thus, the regional industrial ecosystem tends to be closed and closed, self-balancing under the condition of the continuous development of technologies.

At the first stage, the OKVED-2 codes related to the manufacturing industry were disaggregated into separate technologies. Then, by means of logical-structural analysis, the entire set of technologies was transformed into the hierarchy "system technology - component technology - basic technology". In fig. 1 shows a fragment of the technological ecosystem. The decoding of the codes is in Table 1.

The structure of the ecosystem includes a technology that is not related to processing activities according to OKVED-2 "Other scientific research and development in the field of natural and technical sciences (72.19)". This was done after a detailed analysis of the activities of enterprises that provide industrial integrators with digital intelligent technologies, for example, control systems, navigation, tracking, etc.

\section{CONCLUSION}

Thus, the current stage of technological development is characterized by somewhat different pivot points. First, digitalization accelerates the diffusion of technologies and actualizes multidimensional non-hierarchical connections between economic agents. Second, the emergence of technologies is gradually acquiring an increasingly non-stochastic character, which means an increase in the trajectory dependence of technological development. Third, the emergence and development of technologies does not occur as a result of the activities of 
Table 1. System and component technologies.

\begin{tabular}{|c|c|}
\hline $\begin{array}{c}\text { System } \\
\text { technology }\end{array}$ & Component technology \\
\hline $\begin{array}{l}\text { Aircraft } \\
\text { manufacturing, } \\
\text { including } \\
\text { spacecraft } \\
(30.3) \\
\end{array}$ & $\begin{array}{l}26.3 \text { - Production of communication equipment; } 28.11 \text { - Manufacture of engines and turbines, except for } \\
\text { aircraft, automobile and motorcycle engines; } 72.19 \text { - Other scientific research and development in the field } \\
\text { of natural and technical sciences; } 27.40 \text { - Manufacture of electric lamps and lighting equipment; } 26.51 \text { - } \\
\text { Manufacture of instruments and devices for measuring, testing and navigation; }\end{array}$ \\
\hline $\begin{array}{l}\text { Manufacture of } \\
\text { motor vehicles } \\
(29.10)\end{array}$ & $\begin{array}{l}27.9 \text { - Manufacture of other electrical equipment; } 28.11 \text { - Manufacture of engines and turbines, except for } \\
\text { aircraft, automobile and motorcycle engines; } 72.19 \text { - Other scientific research and development in the field } \\
\text { of natural and technical sciences; } 27.40 \text { - Manufacture of electric lamps and lighting equipment; } 29.31 \text { - } \\
\text { Manufacture of electrical and electronic equipment for motor vehicles; } 29.32 \text { - Manufacture of other } \\
\text { components and accessories for motor vehicles; } 22.11 \text { - Manufacture of rubber tires, tires and tubes; } \\
\text { restoration of rubber tires and tires; } 29.2 \text { - Manufacture of bodies for motor vehicles; production of trailers } \\
\text { and semi-trailers; } 22.19 \text { - Manufacture of other rubber products. }\end{array}$ \\
\hline $\begin{array}{l}\text { Manufacture of } \\
\text { machinery and } \\
\text { equipment for } \\
\text { mining and } \\
\text { construction } \\
(28.92)\end{array}$ & $\begin{array}{l}28.22 \text { - Manufacture of handling equipment; transformers and switchgears, as well as instrumentation; } 28.11 \\
\text { - Manufacture of engines and turbines, except for aircraft, automobile and motorcycle engines; } 72.19 \text { - Other } \\
\text { scientific research and development in the field of natural and technical sciences; } 27.40 \text { - Manufacture of } \\
\text { electric lamps and lighting equipment; } 29.31 \text { - Manufacture of electrical and electronic equipment for motor } \\
\text { vehicles; } 29.32 \text { - Manufacture of other components and accessories for motor vehicles; } 22.11 \text { - Manufacture } \\
\text { of rubber tires, tires and tubes; restoration of rubber tires and tires; } 29.2 \text { - Manufacture of bodies for motor } \\
\text { vehicles; production of trailers and semi-trailers; } 27.1 \text { - Manufacture of electric motors, generators, } \\
\text { transformers and switchgear, as well as control and measuring equipment; } 27.2 \text { - Manufacture of electric } \\
\text { accumulators and storage batteries; } 27.3 \text { - Manufacture of cables and cable accessories; lamps and lighting } \\
\text { equipment; } 22.19 \text { - Manufacture of other rubber products; } 27.9 \text { - Manufacture of other electrical equipment }\end{array}$ \\
\hline
\end{tabular}

a firm or platform, but as a result of the complex interaction of various participants within the technological system. The industry is losing its importance, as technologies develop in inter-industry space and are implemented in a distributed production environment.

The study presents an ecosystem approach for analyzing the technological structure of the region. It is shown that looking at the region as an ecosystem of technologies will make it possible to see new points of economic growth.

\section{ACKNOWLEDGMENTS}

The paper is funded by the Russian Foundation for Basic Research (RFFI) and Sverdlovsk oblast within the framework of the scientific project no. 20-410-660032 p_a «Innovative and technological development of a region's industry in the context of the transformation of business architecture and management technologies that produce knowledge and common values: institutional and stakeholder aspects».

\section{REFERENCES}

[1] O. S. Sukharev, Journal of New Economy, (20) 2 (2019).

[2] V. L. Tambovtsev, Journal of New Economy, (20) 2 (2019).

[3] P. David, American Economic Review, (75) 2 (1985).
[4] N.V. Smorodinskaya, D.D. Katukov, Baltic region, (11) 3 (2019)

[5] J. Crespo, P.-A. Balland, R. Boschma, D. Rigby Regional diversification opportunities and smart specialization strategies (2017).

[6] A. M. Thomson, J.L. Perry, Public Administration Review, (66) S1 (2006).

[7] M.G. Jacobides, C. Cennamo, A. Gawer, Strategic Management Journal, 39 (2018).

[8] R. Adner, R. Kapoor, Strategic Management Journal, (3) 31 (2010).

[9] G. Zhang, D. Allaire, V. Shankar, D.A. McAdams, PLoS ONE, (6) 14 (2019). 